\title{
Research on the Impact of E-commerce Policy Instruments on Business Ecosystem in China
}

\author{
—Based on the analysis of policy content
}

\author{
Xiaojun LU \\ Management Experiment Center \\ Harbin University of Commerce \\ Heilongjiang Province, China \\ e-mail: lxjharbin@126.com
}

\author{
Jiaqi SUN \\ Accounting Institute \\ Harbin University of Commerce \\ Heilongjiang Province, China \\ e-mail: 623358496@qq.com
}

\begin{abstract}
In the development and prosperity of the Internet economy, rapid growth of e-commerce, become important in the new economic era a business model. Government through policy tools, as the invisible hand under the market economy system, the development of electronic commerce plays an important role in macroeconomic regulation and control. Based on the policy text data from 2015 to 2016, using system analysis method, analyzes the public policymakers at policy guidance for the electronic commerce development trend, combined with the electronic commerce mode of business ecosystem, this paper analyzes the layout and the emphasis on policy tools, as well as the effect. Research shows that the present stage at the policy level, are of the utmost importance to the economic environment of electronic commerce to create a good environment for electronic commerce development and policy guarantee. Despite China's e-commerce policy launch and improve constantly, but for the policy is still some lack of supply and demand level, cannot fully meet the present ecommerce in the market for capital, technology, product sale, market development, etc, therefore, the electronic commerce policy tools in the process of develop, also should take into account the multiple layout, form a pattern of all aspects of the policy.
\end{abstract}

Keywords-component; e-commerce; system analysis method; policy; the business ecosystem model

\section{INTRODUCTION}

With the advent of the era of "Internet +", the Internet economy gradually to prosperity, e-commerce as one of the important components of the Internet economy, rapid development is increasingly towards the trend of diversification and integration. Electronic commerce as a platform for enterprises primarily, all kinds of medium and support business is complementary comprehensive emerging economic form, formed in the process of the development of the new type of business ecosystem. At home and abroad are mainly concentrated on the study of electronic commerce in four aspects. One is focused on the concept, connotation, ecommerce experience for reference, development model and scope of research [1] - [3]. Two is concentrated in the electronic commerce development present situation and trends, research shows that China's e-commerce development is not balanced, the polarization of clear, and the overall level is not high [4]. Three is focused on e-commerce upgrade path and mode of study, foreign scholars in the study of B2B e-commerce market will be further extended to the financial sector, to have significant influence on bank financial products and services [5]. At the same time, foreign scholars have pointed out that the technology development of electronic commerce will be applied to the possibility of financing system. Chinese scholars from micro level proposed the warehouse receipt pledge financing pattern can be combined with the advantages of e-commerce model; this paper presents a new B2B operating mode [6]. Four is focused on the pilot results, summarize the experience and the analysis of e-commerce at home and abroad based on the different locations of e-commerce construction and analysis of comprehensive experimental zone, Chinese scholars put forward should be on the premise of perfect the work mechanism of the government, should improve the tax reform and development of electronic commerce construction and so on [7].

And the starting point of this article is combed the past two years is given priority to with the central government issued policies, ideas, planning and other laws and regulations, using system analysis method, through to the China policy content analysis, this paper explore the Chinese e-commerce policy factors affect business ecosystem.

\section{E-COMMERce Policy Text SElection}

Given that involves the development of electronic commerce for the government's policy text is relatively complex, in order to ensure that the selected policy text has the characteristics of reliability, systemic, and the accuracy, this paper involves all policy text respectively from the following aspects were selected: one is the selection of source text of the policy, are involved in this paper are from the State Council, policy text the Ministry of Commerce, development and Reform Commission and other relevant agencies of the official website and the related field of the mainstream website public information; the two is from the dispatch unit, dispatch policy text involved in the CPC Central Committee and the State Council departments and departments directly under the main; three is the policy choice of content, this paper studies the text selection policy which are related to electronic commerce policy theme, the 
title of the text or text content must be related to the "electronic "Business", "electricity supplier", "Internet business", "online trade", "cloud data" and other relevant context. According to the selection criteria above, this paper finally sorted out effective policy samples (including planning, measures, opinions and notice etc.) a total of 50, of which 24 copies were issued in 2016, 26 copies were issued on 2015.

TABLE I. A List of RELATEd POLICIES OF ChinA'S CENTRAL ECOMMERCE

\begin{tabular}{|c|c|c|c|}
\hline $\begin{array}{c}\text { Serial } \\
\text { number }\end{array}$ & Title & $\begin{array}{c}\text { Dispatch } \\
\text { unit }\end{array}$ & $\begin{array}{c}\text { Release } \\
\text { time }\end{array}$ \\
\hline 1 & $\begin{array}{l}\text { Guiding opinions on } \\
\text { strengthening the construction } \\
\text { of personal credit system }\end{array}$ & $\begin{array}{l}\text { General } \\
\text { Office of the } \\
\text { State } \\
\text { Council }\end{array}$ & 2016.12 \\
\hline 2 & $\begin{array}{l}\text { In 13th Five-Year, the national } \\
\text { information technology } \\
\text { planning }\end{array}$ & $\begin{array}{l}\text { The State } \\
\text { Council }\end{array}$ & 2016.12 \\
\hline 3 & $\begin{array}{l}\text { Interim Provisions on the } \\
\text { application of the mobile } \\
\text { intelligent terminal application } \\
\text { software to do and distribute } \\
\text { management }\end{array}$ & MIIT & 2016.12 \\
\hline 4 & $\begin{array}{l}\text { Prohibit the delivery of goods } \\
\text { management }\end{array}$ & $\begin{array}{l}\text { Post office, } \\
\text { Ministry of } \\
\text { public } \\
\text { security, } \\
\text { Ministry of } \\
\text { public } \\
\text { security }\end{array}$ & 2016.12 \\
\hline 5 & $\begin{array}{l}\text { Circular on regulating the } \\
\text { operation of cloud services } \\
\text { market (Draft) }\end{array}$ & MIIT & 2016.11 \\
\hline ...... & $\cdots \cdots$ & $\cdots \cdots$ & $\cdots \cdots$ \\
\hline 43 & $\begin{array}{l}\text { Guiding opinions on promoting } \\
\text { the healthy and rapid } \\
\text { development of cross-border } \\
\text { electricity supplier }\end{array}$ & $\begin{array}{l}\text { General } \\
\text { Office of the } \\
\text { State } \\
\text { Council }\end{array}$ & 2015.6 \\
\hline 44 & $\begin{array}{l}\text { Guiding opinions on speeding } \\
\text { up the construction of high } \\
\text { speed broadband network and } \\
\text { reducing the speed of network }\end{array}$ & $\begin{array}{l}\text { The State } \\
\text { Council }\end{array}$ & 2015.5 \\
\hline 45 & $\begin{array}{l}\text { Opinions on further promoting } \\
\text { the development of cross-border } \\
\text { e-commerce through the } \\
\text { functions of inspection and } \\
\text { quarantine }\end{array}$ & AQSIQ & 2015.5 \\
\hline 46 & $\begin{array}{l}\text { Some opinions on promoting } \\
\text { the innovation and development } \\
\text { of postal service }\end{array}$ & $\begin{array}{l}\text { State Post } \\
\text { Bureau }\end{array}$ & 2015.5 \\
\hline 47 & $\begin{array}{l}\text { Opinions on developing } \\
\text { electronic commerce to speed } \\
\text { up the development of new } \\
\text { economic power }\end{array}$ & $\begin{array}{l}\text { The State } \\
\text { Council }\end{array}$ & 2015.5 \\
\hline 48 & $\begin{array}{l}\text { Measures for the administration } \\
\text { of electronic certification } \\
\text { services }\end{array}$ & MIIT & 2015.4 \\
\hline 49 & $\begin{array}{l}\text { Some opinions on promoting } \\
\text { the healthy development of rural } \\
\text { logistics and speeding up the } \\
\text { modernization of Agricultural } \\
\text { Service }\end{array}$ & $\begin{array}{l}\text { MOT, } \\
\text { MOA, } \\
\text { ACFSMC, } \\
\text { the State } \\
\text { Post Bureau }\end{array}$ & 2015.3 \\
\hline 50 & $\begin{array}{l}\text { Opinions on promoting the } \\
\text { innovation and development of } \\
\text { cloud computing to cultivate } \\
\text { new formats of information } \\
\text { industry }\end{array}$ & $\begin{array}{l}\text { The State } \\
\text { Council }\end{array}$ & 2015.1 \\
\hline
\end{tabular}

a. Source: central government and department website

\section{Two DimensionAl Framework OF E-COMMERCE POLICY}

In order to implement electronic commerce emerging economy healthy development, must have a reasonable policy tool as a guide. Policy instruments reflect the public policy decision makers and idea, is the specific methods and measures of policy goals. Have systematic, forward-looking, scientific and rational policy tool is chosen and system construction, not only can achieve the management of the public policy makers, can also influence on the economic, social and ecological benign cycle. Based on the theory of policy tools and business ecosystem theory, constructs the Chinese e-commerce policy text analysis of two-dimensional theoretical framework.

\section{A. X Dimension: Policy Tool Dimension}

Policy research, a research idea of this article is based on Rothwell and Zegveld [8] policy tools thought as the logical starting point, respectively from the several aspects to consider the content of the policy text classification: supply, demand and environment [9]. The supply of policy is mainly reflected in the role of public policy on the development of electronic commerce, the performance of the direct investment of the government, such as land, buildings, equipment, technology, capital and labor can produce objective elements in the material level, in order to build ecommerce industry chain. However, in the specific classification, the supply policy can be subdivided into the input of talents, information support, the support of scientific and technological information and market information, the promotion of technological innovation and management innovation. Demand policy tool has a stimulating effect, mainly in government regulation from the macro level and the development of e-commerce market, expand the demand of e-commerce, from the micro level, the implementation of government procurement policy, service outsourcing and set up overseas institutions and other specific. Environmental policy plays an indirect role, mainly from the perspective of market environment to provide stable and perfect policy environment for the development of electronic commerce, taxation, and regulations specifically in the soft environment, but also the basis of the construction of hard environment logistics, transportation and other hardware [10].

\section{B. Y Dimension: Business Ecosystem Dimension}

E-commerce can not be separated from the Internet platform, online consumption has gradually moved towards the mainstream of consumer spending, and even affect the real economy. Time and space constraints from the business model, make the electronic commerce after its emergence will be rapid growth, the formation of the business ecosystem of multi factor and multi-level, in order to achieve a further re integration of resources. This paper argues that the e-commerce ecosystem is divided into two internal and external circulation system, the internal circulation system includes three aspects: (1) the advantage of group: refers to the leading position in the electronic commerce and the business ecosystem of platform enterprises, integration of resources, enterprises in the direction of the development of 
Electronic Commerce led the industry as a whole, is the electronic commerce pilot [11]; (2) associated groups: refers to support enterprises generated along with the advantages of group e-commerce business ecosystem, such as payment systems, express logistics, network communication, credit rating and other related enterprises. The affiliated groups are dependent on the dominant groups, which provide the essential guarantee for the development of the superior groups; (3) the occasional group is a group that provides additional economic development for the development of the electronic commerce, because of the further development of the group. Like consulting services, electricity supplier advertising marketing, online marketing planning are subordinate groups. The internal circulation system can be called the micro system, which is the basic factor of the business ecosystem [12]. The internal circulation system can be called the micro system, which is the basic factor of the business ecosystem. The external circulation system can also be referred to as the macro system. External environment for the internal cycle to provide a stable guarantee, the internal cycle of the problems encountered, and further promote the continuous improvement of the external system and development. With the gradual development of e-commerce ecosystem, the internal and external systems are moving towards a unified direction. The policy tools of different emphasis in the external system meet the development needs of different groups in the internal system. In this paper, we analyze the impact of policy on the development of ecommerce from the two aspects of internal and external perspectives.

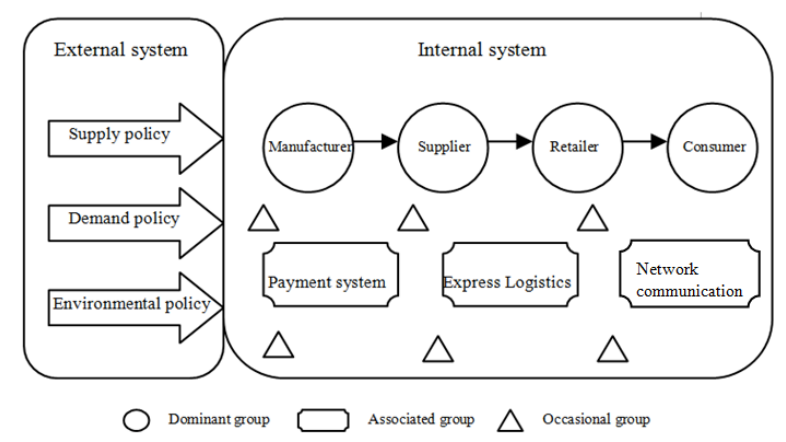

Figure 1.

In summary, we according to the two dimensions of horizontal and vertical axis policy tools and business ecosystem, the evolution of policy tools in this theoretical framework for the commercial ecosystem Fig. 1.

This paper analyzes the present stage of public policy makers in the development of e-commerce to the policy oriented, combined with the business ecosystem model of electronic commerce, and analyzes the policy tool layout and focus, and the effect of.

\section{Policy TeXt ENCOding And Statistical ANALYSIS}

This paper reviews the CPC Central Committee and the State Council from 2015 to 2016 for two years and directly under the Department of policies and regulations, opinions and notice a total of 50. Our policy on the existing 50 text to the coding of the system. First level coding for time series; the two level code is the serial number of the policy text; the three level coding is based on the research of business ecosystem in this paper, which is divided into three types: supply policy, demand policy and environmental policy. Through the analysis of the content of these 50 policy texts, a total of 350 policy text coding. After that, according to the two dimensions of vertical and horizontal, the classification of these 350 codes is given.

TABLE II. China Electronic Commerce Policy TeXt

\begin{tabular}{|c|c|c|c|c|}
\hline & & $\begin{array}{l}\text { Dominant } \\
\text { group } \\
51.14 \%\end{array}$ & $\begin{array}{l}\text { Associated } \\
\text { group } \\
44.86 \%\end{array}$ & $\begin{array}{c}\text { Occasional } \\
\text { group } \\
4 \%\end{array}$ \\
\hline \multirow{4}{*}{$\begin{array}{l}\text { Supply } \\
\text { policy } \\
\text { (63) }\end{array}$} & $\begin{array}{c}\text { personnel } \\
\text { training (16) }\end{array}$ & 9 & 7 & \\
\hline & $\begin{array}{l}\text { Information } \\
\text { support (6) }\end{array}$ & 2 & 4 & \\
\hline & $\begin{array}{l}\text { Capital } \\
\text { investment } \\
(10)\end{array}$ & & 10 & \\
\hline & $\begin{array}{c}\text { Technologica } \\
1 \text { innovation } \\
(31)\end{array}$ & 18 & 12 & 1 \\
\hline \multirow{6}{*}{$\begin{array}{c}\text { Environ } \\
\text { mental } \\
\text { polic } \\
(274)\end{array}$} & $\begin{array}{c}\text { goal } \\
\text { programming } \\
(82)\end{array}$ & 56 & 20 & 6 \\
\hline & $\begin{array}{c}\text { Infrastructure } \\
(54)\end{array}$ & 30 & 22 & 2 \\
\hline & $\begin{array}{c}\text { Financial } \\
\text { support (37) }\end{array}$ & 12 & 25 & \\
\hline & $\begin{array}{c}\text { Tax } \\
\text { preference } \\
(5)\end{array}$ & 4 & 1 & \\
\hline & $\begin{array}{c}\text { Regulation } \\
\text { control (55) }\end{array}$ & 22 & 31 & 2 \\
\hline & $\begin{array}{c}\text { Policy } \\
\text { strategy (41) }\end{array}$ & 17 & 21 & 3 \\
\hline \multirow{3}{*}{$\begin{array}{l}\text { Demand } \\
\text { policy } \\
\text { (13) }\end{array}$} & $\begin{array}{l}\text { Government } \\
\text { purchase (1) }\end{array}$ & 1 & & \\
\hline & $\begin{array}{c}\text { Overseas } \\
\text { institutions } \\
(11)\end{array}$ & 7 & 4 & \\
\hline & $\begin{array}{c}\text { Service } \\
\text { Outsourcing } \\
\text { (1) }\end{array}$ & 1 & & \\
\hline
\end{tabular}

b. Note: the contents of the table are obtained by the author 


\section{A. An Analysis of the Dimensions of Policy Instruments}

Based on the analysis on the table, the following conclusions can be drawn from the quantitative point of view, the environmental policy tools in the proportion of $78.29 \%$ in the first row, the number reached 274 , followed by the supply policy, the proportion reached $18 \%$, the number was 63 , in second place, while the number of supply administration policy at least, only 13 , accounting for $3.71 \%$. From a variety of policy tools can be seen clearly that the government is more inclined to improve the business environment of e-commerce, in order to build a business ecosystem.

From the supply policy perspective, a large number of technological innovation, which shows that in the mobile data and Internet economy today, multi-level innovation has become a great power to drive the development of electronic commerce. The innovation of e-commerce includes not only the innovation of business model, but also the innovation and development of communication facilities, business models, technology applications and product services. The number of personnel training is ranked in second place, so in the context of the development of electronic commerce, technical personnel still plays a key role, high level talents, high-end occupation managers are extremely rare professional talents in the development of electronic commerce, but also to continue training and introduction to the factors of fresh electricity supplier industry to go. In contrast, the number of information support and capital investment policy provisions are small, especially the information support entries only 6, which shows that the current degree of e-commerce information construction is limited. Although the development of cloud computing, big data, networking and other information technology promotion, information construction has achieved initial success, but in the information sharing, radiation range, information transmission, data and other aspects of the use of the degree of lack of policy support and guidance. The number of funding policy provisions for 10, this shows that in the electronic commerce in the allocation of funds is still some lack of resources, lack of special funds, special funds as a supplement.

From the perspective of environmental policy, target planning for entry the largest number is 82 , accounting for $30 \%$ of the total environmental policy items, thus, the policy text of the central government are still in the target outline as the main content, fully explain the public policymakers realize the good business economy needs to strengthen the organization leadership, specification for the development goals, development direction from the master pattern of ecommerce, e-commerce new guidance from the high angle change. The infrastructure and regulatory policy on the number of entries from the former 54, be roughly the same, the latter is 55 . The infrastructure for the development of ecommerce, which contains both the communication network and logistics platform, warehousing and other hard conditions of infrastructure construction, improve also contains information network, network information sharing cloud computing ability, big data processing and other soft conditions. In today's society under the rule of law, legal protection under the network platform based on highlights the importance of electronic commerce, is different from the real economy, the personal credit system construction to the data network authentication of electronic payment, are in need of legal weapons to the main body of the electronic commerce economic rights protection. In the environmental policy, the number of financial support and preferential tax policy items slightly behind, which reflects the current development of China e-commerce are still missing, in the field of Finance and tax aspects of the construction should be improved, especially the tax policy, we should draw lessons from foreign e-commerce experience of developed countries, as soon as possible to improve the shortage of electronic commerce tax China the promotion of economic prosperity and further expand the electricity supplier.

From the point of view of demand policy, the number of policy texts is far lower than that of supply and environmental policies. Among them, the text of the policy for overseas institutions, for the 11, while government procurement and outsourcing services accounted for only one policy text entry. China's vast territory, border stretches, many of the neighbors, the rapid development of crossborder electricity supplier. And China's policy tools in this regard is far from enough to support the rapid development of domestic and international electricity supplier market, the country still needs more attention in this regard.

\section{B. From the Perspective of Business Ecosystem}

Statistics from the policy text can be seen clearly, the number of current policy texts is more concentrated in the dominant group and associated group, especially the dominant groups, accounting for the overall number of policy text $51.14 \%$, reached more than half. This shows that in the process of the development of electronic commerce, the focus of public decision makers will continue to develop on the production, circulation and consumption of the main part, mainly to increase support and construction of business platform, commodity logistics and transaction subject advantage groups, integrate the advantages of resources to enhance the development of space, which is consistent with the trend and the trend of development of electronic business. The government for the payment system, electronic authentication, media and other associated groups into less than advantage group, but there are still more than $44.86 \%$, visible along with the electronic commerce system of continuous improvement, ecosystem development towards a virtuous circle, toward the vertical dimension associated group further development, and gradually formed a complete market pattern. Consulting services, shop design, network marketing, and even see the smallest group, only $4 \%$ and more focused on environmental policy level. Further guidance and planning in the process of e-commerce development of derivative products still need policy tools, along with the "Internet plus" era, e-commerce has ushered in a new round of opportunity for development, how to make e-commerce with the Internet economic prosperity to a qualitative leap, researchers need to think about is still the problem of public policy making. 


\section{IMPACT STUDY}

Analysis of the statistics of the Chinese e-commerce policy text content based on the results, it is not difficult to find China current electronic commerce policy exists some unreasonable places, the process of development efforts and market macro guidance did not reach consensus. Chinese will focus on creating the economic environment at the beginning of the development of electronic commerce, the development of an open Easy Access for it, which is why Chinese e-commerce has made outstanding achievements in a short period of time, but the development of e-commerce after the potential shortage, the supply and demand has not yet reached the balance. The development of e-commerce economy, from the policy level to stimulate consumer demand, and by the government to provide electricity for the development of investment funds to protect. Policy tools from the external environment of e-commerce business ecosystem to internal development should conform to the equilibrium principle, the innovation of business mode; promote the development of electronic commerce and the depth of the vertical horizontal expansion scope, clear coverage of e-commerce, network formation development situation with innovation as the core of the multi dimension.

The development of electronic commerce to fit the needs of information construction of the China, meet China achieve "13th Five-Year" planning political goals. Different types of policy instruments provide favorable support and guarantee for the expansion of different organizations in the business ecosystem, and the government is still in the core of ecommerce business ecosystem. However, the policy documents in the State Council and the ministries and commissions under the lower levels of government and relevant departments, the implementation process still needs further detailed investigation, the implementation of ecommerce enterprises to produce economic effect after it remains to be further investigation and research.

This paper analyzes the guiding role of policy tools for the development of e-commerce plays through policy text tools and electronic business ecosystem model two latitudes, see China currently in the field of electronic commerce policy implementation situation and the current e-commerce system directly. According to the different proportion of supply, demand and environment in the three aspects of the supply and demand, and the distribution in the business ecosystem, the paper analyzes the influence of policy instruments on the development of e-commerce. In this paper, the sample collection of policy text tools is limited, and only studied the policy text data from 2015 to 2016. If we can expand the number of policy texts, the reliability of statistical analysis will be strengthened. In addition, this paper focus on the relevant policies of the State Council and the ministries of text and administrative departments, the place has not been collected in various provinces and cities in the implementation of the electronic commerce laws and local administrative policies, if further expand the text content, you can make more specific and improved the results of statistical analysis.

\section{REFERENCES}

[1] Song Ling. Measurement and method of informatization level [M]. Beijing: Economic Science Press, 2001.

[2] Zhang Rui. Measurement of development level of China's Internet economy [J]. Economic theory and economic management, 2001 (9): 47.

[3] Qin Meifen. Improvement of the method of calculating the level of informatization and its case study [J]. Information theory and practice, 2000 (5) 325-327.

[4] Wei Jianliang, Xie Yangqun. Electronic commerce level measure theory.[J]. Journal of information, 2006 (2):91 - 93.

[5] Keah Choon Tan, Steven B. Lyman, "Supply Chain Man-agement: A Strategic Perspective", International Journal of Operations\& Production Management,2000,(6).

[6] Zhang Qiang: Study on the electronic commerce operation mode of intermediary B2B warehouse receipt pledge fusion, Tianjin University master thesis, 2007.

[7] Li Nan, Ke. In the cross-border electricity supplier in Hangzhou comprehensive experimental zone construction analysis, obstacle and Countermeasure of [J]. Electronic commerce, 2016 (12).

[8] Roy Rhthwell, Walter Zegveld. Reindesdalization and Techology [M].Logman Group Limited,1985,104.

[9] Gong Qinlin, Liu Ci. Evaluation of the regional innovation system in a three-dimensional analysis framework based on the perspective of "1+10" -- Taking Chengdu city as an example.[J]. Innovation policy system of soft science, 2015 (29).14-18.

[10] Xie Qing, Jiyong. Innovation policy how to promote the development of new energy automotive industry in China -- Analysis of policies and policy tools of innovation value chain based on.[J]. Science and technology management, 2015 (06): 3-14.

[11] Xu Weiguang. Comparison, criticism and construction of the theory of production factors. [J] Economics, 2013, (11): 28-36.

[12] Xu Weiguang. A constructive analysis of the theory of production factors based on the theory of, [J]. Economist, 2012, (08):11-18. 